\title{
Ekonomi Pembangunan Terhadap Pengangguran di Provinsi Jambi
}

oleh:

*) Ir. Afrizal., M.E.

**) Dosen Tetap STMIK Nurdin Hamzah Jambi

\begin{abstract}
Unemployment in developing countries such as Indonesia, the economic development of this country as a growing number of unemployment is a problem that is more complicated and more serious than the problem of changes in income distribution are less profitable lowincome residents

Unemployment in Jambi Province has reached tens of thousands of people is an urgent problem that must be solved because of the impact of unemployment it would be very dangerous to the social order of life. It is a fact that various social evils such as theft I muggings/robberies, prostitution, Jula buy children, street children and others merupakandampakdaripengangguran.
\end{abstract}

Keywords : Economic Development, Unemployment

\section{PENDAHULUAN}

\section{Latar Belakang}

Pengangguran di Negara-negara berkembang seperti Indonesia, dalam pembangunan ekonomi di Negara seperti ini pengangguran yang semakin bertambah jumlahnya merupakan masalah yang lebih rumit dan lebih serius daripada masalah perubahan dalam distribusi pendapatan yang kurang menguntungkan penduduk yang berpendapatan terendah. Keadaan di Negara-negara berkembang dalam beberapa dasawarsa ini menunjukan bahwa pembangunan ekonomi yang telah tercipta tidak sanggup mengadakan kesempatan kerja yang lebih cepat daripada pertambahan penduduk yang berlaku. Oleh karenanya, masalah pengangguran yang mereka hadapi dari tahun ke tahunsemakinbertambahserius.

Pengangguran terjadi disebabkan antara lain, yaitu karena jumlah lapangan kerja yang tersedia lebih kecil dari jumlah pencari kerja. Juga kompetensi pencari kerja tidak sesuai dengan pasar kerja. Selain itu juga kurang efektifnya informasi pasar kerja bagi para pencari kerja. Fenomena pengangguran juga berkaitan erat dengan terjadinya pemutusan hubungan kerja, yang disebabkan antara lain; perusahaan yang menutup/mengurangi bidang usahanya akibat krisis ekonomi atau keamanan yang kurang kondusif; peraturan yang menghambat inventasi; hambatan dalam proses ekspor impor, dan lain-lain. 
Masalah pengangguran akan menimbulkan dampak yang negatif bagi kelangsungan hidup berbangsa dan bernegara. Dampak negatif dari pengangguran adalah kian beragamnya tindakan kriminal, makin banyaknya jumlah anak jalanan, pengemis, pengamen perdagangan anak dan sebagainya sudah menjadi patologi sosial atau kuman penyakit sosial yang menyebar bagaikan virus yang sulit di berantas.

\section{Rumusan Masalah}

1. Apa yang menjadi masalah pengangguran di Provinsi Jambi?

2. Bagaimana keadaan pengangguran di Provinsi Jambi?

3. Apakah pengangguran mengakibatkan kemiskinan?

\section{Tujuan Penelitian}

Tujuan dari penelitian ini adalah untuk mengetahui seberapa besarnya pengangguran yang terjadi di Provinsi Jambi, masalah dan keadaan pengangguran, serta untuk mengetahui factor-faktor apa saja yang menimbulkan terjadinya pengangguran dan juga untuk mengetahui bagaiamana sikap pemerintah Provinsi Jambi dalam mengatasi pengangguran.

\section{Manfaat Penelitian}

Penelitian ini diharapkan dapat memberikan manfaat bagi :

1. Penulis.

Karena dengan penelitian ini dapat menambah pengetahuan serta wawasan bagi penulis mengenai masalah pengangguran yang ada di Provinsi Jambi sehingga kita yang semakin tahun semakin meningkat jumlahnya akibat dari beberapa faktor,baik dari dalam maupun dari luar.

2. Masyarakat

Masyarakat juga dapat mengetahui penyebab apa saja yang menimbulkan pengangguran serta masyarakat juga dapat bertindak langsung dalam upaya mengatasi masalah pengangguran.

3. Secara akademis :

diharapkan dari hasil penelitian ini dapat digunakan sebagai referensi bagi penelitian lainnya, terutama bagi peneliti yang tertarik pada bidang ekonomi pembangunan. 


\section{Secara praktis :}

Temuan-temuan dalam penelitian ini dapat sebagai bahab masukan atau informasi bagi pemerintah provinsi jambi. Mahasiswa mendapat mengembangkan kembali dari hasil karya ilmiah ini.

\section{PEMBAHASAN}

\section{Landasan teori}

Pengertian Pengangguran

Pengertian penganguran adalah sebutan untuk suatu keadaan di mana masyarakat tidak bekerja.Menganggur adalah mereka yang tidak mempunyai pekerjaan dalam kurun waktu seminggu sebelum pencacahan dan sedang berusaha mencari pekerjaan dan ini mencangkup mereka yang sedang menunggu panggilan terhadap lamaran kerja yang di ajukan atau sedang tidak mencari kerja karena beranggapan tidak ada kesempatan kerja yang tersedia untuk dirinya walaupun dia sanggup. keadaan yang ideal, diharapkan besarnya kesempatan kerjasama dengan besarnya angkatan kerja, sehingga semua angkatan kerja akan mendapatkan pekerjaan.

Pada kenyataannya keadaan tersebut sulit untuk dicapai. Umumnya kesempatan kerja lebih kecil dari pada angkatan kerja, sehingga tidak semua angkatan kerja akan mendapatkan pekerjaan, maka timbullah penggangguran. Pengangguran sering diartikan sebagai angkatan kerja yang belum bekerja atau bekerja secara tidak optimal. Berdasarkan pengertian tersebut, maka pengangguran dapat dibedakan menjadi tiga macam.

1. Pengangguran Terbuka (Open Unemployment).

Pengangguran terbuka adalah tenaga kerja yang betul-betul tidak mempunyai pekerjaan. Pengangguran ini terjadi ada yang karena belum mendapat pekerjaan padahal telah berusaha secara maksimal dan ada juga yang karena malas mencari pekerjaan atau malas bekerja.

2. Pengangguran Terselubung (Disguessed Unemployment).

3. Pengangguran terselubung yaitu pengangguran yang terjadi karena terlalu banyaknya tenaga kerja untuk satu unit pekerjaan padahal dengan mengurangi tenaga kerja tersebut sampai jumlah tertentu tetap tidak mengurangi jumlah produksi. Pengangguran terselubung bisa juga terjadi karena seseorang yang bekerja tidak sesuai dengan bakat dan kemampuannya, akhirnya bekerja tidak optimal. 
Contoh:

Pada sebuah kantor terdapat 10 tenaga administrasi yang menangani pekerjaan yang ada. Padahal dengan jumlah tenaga 6 orang saja semua pekerjaan dapat terselesaikan dengan baik. Akibatnya para pegawai tersebut bekerja tidak optimal dan bagi kantor tentu merupakan suatu pemborosan.

4. Setengah Menganggur (Under Unemployment).

Setengah menganggur ialah tenaga kerja yang tidak bekerja secara optimal karena tidak ada pekerjaan untuk sementara waktu. Ada yang mengatakan bahwa tenaga kerja setengah menganggur ini adalah tenaga kerja yang bekerja kurang dari 35 jam dalam seminggu atau kurang dari 7 jam sehari. Misalnya seorang buruh bangunan yang telah menyelesaikan pekerjaan di suatu proyek, untuk sementara menganggur sambil menunggu proyek berikutnya.

Bisakah Anda memberi contoh lain mengenai jenis pengangguran di atas? Coba sebutkan lalu cocokkan ciri-ciri pengangguran tadi dengan contoh yang Anda sebutkan. Apabila digambarkan dengan bagan, maka jenis pengangguran ini akan nampak sebagai berikut:

\section{Jenis pengangguran}

1. Pengangguran Friksional (Transisional).

Pengangguran ini timbul karena perpindahan orang-orang dari satu daerah ke daerah lain, dari satu pekerjaan ke pekerjaan yang lain dan karena tahapan siklus hidup yang berbeda.

Contoh:

- Perpindahan tenaga kerja dari sektor pertanian ke sektor industri, untuk sementara menganggur.

- Berhenti dari pekerjaan yang lama, mencari pekerjaan yang baru yang lebih baik

2. Pengangguran Struktural

Pengangguran struktural adalah pengangguran akibat keadaan ekonomi. Perubahan struktur ekonomi akhirnya mengalami perubaahana dalam kebutuhan tenaga kerja. Struktur ekonomi agraris berubah menjadi sistem struktur Industri, yang menuntut perubahan keterampilan yang dapat menunjang industri. Beberapa kasus pengangguran struktural terjadi pada 1998, pada saat bangsa Indonesia mengalami krisis moneter. 
Banyak pekerja pabrik, pegawai bank dan perusahaan-perusahaan serta lembagalembaga lainnya yang mengalami kerugian, sehingga dilakukan pemutusan hubungan kerja (PHK). Pada tahun tersebut, tingkat pengangguran di Indonesia begitu tinggi. Pengangguran struktural dapat diatasi jika pemerintah melakukan dan mengeluarkan peraturan serta kebijakan yang memihak rakyat. Di samping itu, pengganggur pun harus memperdalam keahlian dan kemampuannya.

Pengangguran ini terjadi karena adanya perubahan dalam struktur perekonomian yangmenyebabkan kelemahan di bidang keahlian lain. Contoh: Suatu daerah yang tadinya agraris (pertanian) menjadi daerah industri, maka tenaga bidang pertanian akan menganggur.

3. Pengangguran Siklikal atau Siklus atau Konjungtural.

Pengangguran ini terjadi karena adanya gelombang konjungtur, yaitu adanya resesi atau kemunduran dalam kegiatan ekonomi. Contoh: Di suatu perusahaan ketika sedang maju butuh tenaga kerja baru untuk perluasan usaha. Sebaliknya ketika usahanya merugi terus maka akan terjadi PHK (Pemutusan Hubungan Kerja) atau pemecatan.

4. Pengangguran Musiman (Seasonal) Pengangguran musiman terjadi karena adanya perubahan musim. Contoh: pada musim panen, para petani bekerja dengan giat, sementara sebelumnya banyak menganggur.

5. Pengangguran Teknologi Pengangguran ini terjadi karena adanya penggunaan alat-alat teknologi yang semakin modern. Contoh, sebelum ada penggilingan padi, orang yang berprofesi sebagai penumbuk padi bekerja, setelah ada mesin penggilingan padi maka mereka tidak bekerja lagi.

6. Pengangguran Politis Pengangguran ini terjadi karena adanya peraturan pemerintah yang secara langsung atau tidak, mengakibatkan pengangguran. Misalnya penutupan Bankbank bermasalah sehingga menimbulkan PHK.

7. Pengangguran Deflatoir Pengangguran deflatoir ini disebabkan tidak cukup tersedianya lapangan pekerjaan dalam perekonomian secara keseluruhan, atau karena jumlah tenaga kerja melebihi kesempatan kerja, maka timbulah pengangguran. Pengangguran atau tuna karya adalah istilah untuk orang yang tidak bekerja sama sekali, sedang mencari kerja, bekerja kurang dari dua hari selama seminggu, atau seseorang yang sedang berusaha mendapatkan pekerjaan yang layak. Pengangguran umumnya disebabkan karena jumlah angkatan kerja atau para pencari kerja tidak sebanding dengan jumlah lapangan kerja 
yang ada yang mampu menyerapnya. Pengangguran seringkali menjadi masalah dalam perekonomian karena dengan adanya pengangguran, produktivitas dan pendapatan masyarakat akan berkurang sehingga dapat menyebabkan timbulnyakemis kinan dan masalah-masalah sosial lainnya. Tingkat pengangguran dapat dihitung dengan cara membandingkan jumlah pengangguran dengan jumlah angkatan kerja yang dinyatakan dalam persen. Ketiadaan pendapatan menyebabkan penganggur harus mengurangi pengeluaran konsumsinya yang menyebabkan menurunnya tingkat kemakmuran dan kesejahteraan. Pengangguran yangberkepanjangan juga dapat menimbulkan efek psikologis yang buruk terhadap penganggur dan keluarganya. Tingkat pengangguran yang terlalu tinggi juga dapat menyebabkan kekacauan politik keamanan dan sosial sehingga mengganggu pertumbuhan dan pembangunan ekonomi. Akibat jangka panjang adalah menurunnya GNP dan pendapatan per kapita suatu negara. Di negara-negara berkembang seperti Indonesia, dikenal istilah "pengangguran terselubung" di mana pekerjaan yang semestinya bisa dilakukan dengan tenaga kerja sedikit, dilakukan oleh lebih banyak orang.

8. Penganggur Voluntary Penganggur voluntary adalah penganggur yang sebenarnya mampu bekerja, namun memilih tidak bekerja karena mempunyai usaha. Misalnya, membuka rental mobil, membuka kos-kosan, dan lain-lain. Penganggur voluntary bisa membuka lapangan pekerjaan untuk penganggur lainnya.

\section{Penyebab Pengangguran}

Beberapa hal yang menyebabkan pengangguran antara lain:

a. Penduduk yang relatif banyak.

b. Pendidikan dan keterampilan yang rendah.

c. Angkatan kerja tidak dapat memenuhi persyaratan yang diminta dunia kerja

d. Teknologi yang semakin modern

e. Pengusaha yang selalu mengejar keuntungan dengan cara melakukan

\section{Dampak Pengangguran}

Pengangguran bisa menimbulkan dampak negatif, yang bukan hanya bagi sang penganggur, namun juga bagi masyarakat di sekitarnya. Pengangguran membawa 
permasalahan ekonomi suatu keluarga, yang bisa menyebabkan terganggunya kondisi psikis seseorang.

Misalnya, terjadi pembunuhan akibat masalah ekonomi, terjadi pencurian dan perampokan akibat masalah ekonomi, rendahnya tingkat kesehatan dan gizi masyarakat, kasus anak-anak terkena busung lapar, juga terjadinya kekacauan sosial dan politik seperti terjadinya demonstrasi dan perebutan kekuasaan.

\section{Tujuan Dan Kebijakan Pemerintah}

Beberapa Tujuan Kebijakan Pemerintah

a. Tujuan Bersifat Ekonomi:

1. Menyediakan lowongan pekerjaan dari tahun ke tahun

2. Meningkatkan taraf kemakmuran masyarakat

3. Memperbaiki pembagian pendapatan

b. Tujuan Bersifat Social dan Politik :

1. Meningkatkan kemakmuran keluarga dan kestabilan keluarga, di dalam suatu rumah tangga harus ada yang mempunyai pekerjaan guna memenuhi kebutuhannya.

2. Menghindari masalah kejahatan, karena semakin tinggi pengangguran maka semakin tinggi kasus kejahatan.

3. Mewujudkan kestabilan politik, dalam perekonomian yang tingkat penganggurannya tinggi masyarakat sering kali melakukan demontrasi dan mengemukakan kritik atas pemimpin pemerintah dan ini dapat menghambat kegiatan ekonomi. Sebagai akibatnya perkembangan ekonomi yang terlambat berakibat pangangguran memburuk.

c. Kebijakan Pemerintah:

1. Pemerintah memberikan bantuan wawasan, pengetahuan dan kemampuan jiwa kewirausahaan kepada Usaha Kecil dan Menengah (UKM) berupa bimbingan teknis dan manajemen memberikan bantuan modal lunak jangka panjang, perluasan pasar. Serta pemberian fasilitas khusus agar dapat tumbuh secara mandiri dan andal bersaing di bidangnya. Mendorong terbentuknya kelompok usaha bersama dan lingkungan usaha yang menunjang dan mendorong terwujudnya pengusaha kecil dan menengah yang mampu mengembangkan usaha, menguasai 
teknologi dan informasi pasar dan peningkatan pola kemitraan UKM dengan BUMN, BUMD, BUMS dan pihak lainnya.

2. Segera melakukan pembenahan, pembangunan dan pengembangan kawasankawasan, khususnya daerah yang tertinggal dan terpencil sebagai prioritas dengan membangun fasilitas transportasi dan komunikasi. Ini akan membuka lapangan kerja bagi para penganggur di berbagai jenis maupun tingkatan. Harapan akan berkembangnya potensi wilayah Negara Kesatuan Republik Indonesia (NKRI) baik potensi sumber daya alam, sumber daya manusia.

3. Segera membangun lembaga sosial yang dapat menjamin kehidupan penganggur. Seperti PT Jaminan Sosial Tenaga Kerja (PT Jamsostek) Dengan membangun lembaga itu, setiap penganggur di Indonesia akan terdata dengan baik dan mendapat perhatian khusus. Secara teknis dan rinci.

4. Segera menyederhanakan perizinan dan peningkatan keamanan karena terlalu banyak jenis perizinan yang menghambat investasi baik Penanamaan Modal Asing maupun Penanaman Modal Dalam Negeri. Hal itu perlu segera dibahas dan disederhanakan sehingga merangsang pertumbuhan iklim investasi yang kondusif untuk menciptakan lapangan kerja.

5. Mengembangkan sektor pariwisata dan kebudayaan Indonesia (khususnya daerahdaerah yang belum tergali potensinya) dengan melakukan promosi-promosi keberbagai negara untuk menarik para wisatawan asing, mengundang para investor untuk ikut berpartisipasi dalam pembangunan dan pengembangan kepariwisataan dan kebudayaan yang nantinya akan banyak menyerap tenaga kerja daerah setempat.

6. Melakukan program sinergi antar BUMN atau BUMS yang memiliki keterkaitan usaha atau hasil produksi akan saling mengisi kebutuhan. Dengan sinergi tersebut maka kegiatan proses produksi akan menjadi lebih efisien dan murah karena pengadaan bahan baku bisa dilakukan secara bersama-sama. Contoh, PT Krakatau Steel dapat bersinergi dengan PT. PAL Indonsia untuk memasok kebutuhan bahan baku berupa pelat baja.

7. Dengan memperlambat laju pertumbuhan penduduk (meminimalisirkan menikah pada usia dini) yang diharapkan dapat menekan laju pertumbuhan sisi angkatan kerja baru atau melancarkan sistem transmigrasi dengan mengalokasikan penduduk 
padat ke daerah yang jarang penduduk dengan difasilitasi sektor pertanian, perkebunan atau peternakan oleh pemerintah.

8. Menyeleksi Tenaga Kerja Indonesia (TKI) yang akan dikirim ke luar negeri. Perlu seleksi secara ketat terhadap pengiriman TKI ke luar negeri. Sebaiknya diupayakan tenaga-tenaga terampil. Hal itu dapat dilakukan dan diprakarsai oleh Pemerintah Pusat dan Daerah.

9. Segera harus disempurnakan kurikulum dan sistem pendidikan nasional (Sisdiknas). Sistem pendidikan dan kurikulum sangat menentukan kualitas pendidikan yang berorientasi kompetensi. Karena sebagian besar para penganggur adalah para lulusan perguruan tinggi yang tidak siap menghadapi dunia kerja.

10. Segera mengembangkan potensi kelautan dan pertanian. Karena Indonesia mempunyai letak geografis yang strategis yang sebagian besar berupa lautan dan pulau-pulau yang sangat potensial sebagai negara maritim dan agraris. Potensi kelautan dan pertanian Indonesia perlu dikelola secara baik dan profesional supaya dapat menciptakan lapangan kerja yang produktif

d. Tindakan Pemerintah dalam mengatasi pengangguran:

- Mengurangi pajak

- Mendorong lebih banyak investasi membari subsidi

- Meningkatkan taraf kemakmuran masyarakat

- Memperbaiki pembagian pendapatan

- Menghindari masalah kejahatan

- Menambah keterampilan masyarakat

\section{METODE PENELITIAN}

\section{Materi Penelitian}

Penelitian ini menggunakan metode deskriptif . deskriptif adalah salahsatu metode penelitian dengn cara observasi melalui internet dan buku-buku, yang dapat memberikan fakta secara aktual dan kontekstual. Data yang diperoleh hanya berlaku bagi tempat, waktu, dan kondisi penelitian.

Dalam melakukan penelitian ini, penulis memakai metode observasi dengan membaca, mencatat serta melihat keadaan secara langsung maupun dari pemberitaan media elektronik selain itu penulis juga mendapatkan informasi ini melalui internet. 


\section{Teknik Pengumpulan data}

Dalam penelitian ini metode yang akan digunakan adalah:

1. Metode angket atau Kuesioner Yaitu sejumlah pertanyaan tertulis yang digunakan untuk memperoleh informasi dari responden dalam arti laporan tentang pribadinya atau hal-hal yang Ia ketahui. Dari pengertian diatas dapat diketahui bahwa Angket adalah suatu cara pengumpulan informasi dengan penyampaian suatu daftar tentang hal-hal yang diteliti.

2. Metode Observasi Yaitu memperlihatkan sesuatu dengan mempergunakan mata. Atau observasi juga disebut pengamatan, meliputi kegiatan pemusatperhatian terhadap sesuatu objek dengan menggunakan seluruh indra. Tempat pengumpulan bahan (sampah non organik) dari rumah-rumah tetangga dan tempat terdapat sampah non organic.

\section{Teknik Analisis dan Pengumpulan Data}

Data dan informasi yang telah di kumpulkan akan diolah dengan beberapa metode analisa data sebagai berikut:

1. Analisa Kualitatif yaitu mengamati.memahami, dan menafsirkan setiap data yang ada kaitannya dengan rumusan masalah.

2. Analisa Deskriptif yaitu setelah data dan informasi terkumpul maka dilanjutkan penyusunan dan penghimpunan dan membahasnya serta menginterprestasikan berdasarkan logika dan teori yang relavan untuk menarik kesimpulan.

\section{HASIL DAN PEMBAHASAN}

\section{KEADAAN KETENAGAKERJAAN}

1. Jumlah angkatan kerja di Provinsi Jambi pada Februari 2014 mencapai 1.570,3 ribu orang, bertambah sebanyak 103,3 ribu orang dibanding angkatan kerja Agustus 2013 sebanyak 1.467,0 ribu orang namun berkurang sebanyak 32,2 ribu orang jika dibanding Februari 2013.

2. Jumlah penduduk yang bekerja di Provinsi Jambi pada Februari 2014 mencapai 1.531,1 ribu orang, bertambah sebanyak 133,8 ribu orang dibanding keadaan pada Agustus 2013 sebanyak 1.397,3 ribu orang atau berkurang 25,7 ribu orang dibanding keadaan Februari 2013.

3. Tingkat Pengangguran Terbuka (TPT) di Provinsi Jambi pada Februari 2014 mencapai 2,50 persen, mengalami penurunan dibanding TPT Agustus 2013 sebesar 4,76 persen dan TPT Februari 2013 sebesar 
2,86 persen.

4. Selama setahun terakhir (Februari 2013-Februari 2014), jumlah penduduk yang bekerja mengalami kenaikan dibeberapa sektor, terutama di Sektor Perdagangan sebanyak 36,1 ribu orang (14,35 persen), Jasa Kemasyarakatan sebanyak 29,9 ribu orang (1,23 persen), serta Sektor Keuangan sebanyak 12,3 ribu orang (49,2 persen). Sedangkan sektor yang mengalami penurunan adalah Sektor Pertanian, Sektor Industri dan Sektor Konstruksi.

Berdasarkan jumlah jam kerja pada Februari 2014, sebanyak 840,5 ribu orang (54,89 persen) bekerja diatas 35 jam perminggu, sedangkan penduduk bekerja dengan jumlah jam kerja kurang dari 15 jam perminggu mencapai 93,6 ribu orang $(6,11$ persen).

Pada Februari 2014,penduduk bekerja pada jenjang pendidikan SD kebawah masih tetap mendominasi yaitu sebanyak 670.02 ribu orang (43,76 persen), sedangkan penduduk bekerja dengan pendidikan Diploma sebanyak 48,0 ribu orang (3.13 persen) dan penduduk bekerja dengan pendidikan Universitas sebanyak 138,9 ribu orang $(9,07$ persen).

\section{Angkatan Kerja, Penduduk yang Bekerja dan Pengangguran}

Keadaan ketenagakerjaan di Provinsi Jambi pada Februari 2014 diwarnai perubahan beberapa indikator seperti digambarkan pada tabel 1. Jumlah angkatan kerja pada Februari 2014 bertambah sebanyak 103,3 ribu orang dibanding keadaan Agustus 2013 namun berkurang sebanyak 32,2 ribu orang jika dibanding keadaan Februari 2013. Penduduk yang bekerja pada Februari 2014 bertambah sebanyak 133,8 ribu orang dibanding keadaan Agustus2013, atau berkurang sebanyak 25,7 ribu orang dibanding keadaan setahun yang lalu (Februari 2013). Sementara jumlah penganggur pada Februari 2014 mengalami penurunan yaitu sebanyak 30,5 ribu orang jika dibanding keadaan Agustus 2013, dan berkurang sebanyak 6,5 ribu orang jika dibanding keadaan Februari 2013.Dalam setahun terakhir, Tingkat Partisipasi Angkatan Kerja (TPAK) Provinsi Jambi fluktuaif, pada Februari 2013 TPAK sebesar 71,92 persen, turun signifikan pada Agustus 2013 menjadi 62,68 persen kemudian naik pada Februari 2014 menjadi 66,51 persen.

Tabel 1. Penduduk Usia 15 Tahun Ke Atas Menurut Jenis Kegiatan Utama, 2012-2014

\begin{tabular}{|c|c|c|c|c|c|c|}
\hline \multirow{2}{*}{ Jenis Kegiatan Utama } & \multicolumn{2}{c|}{ 2012* } & \multicolumn{2}{|c|}{ 2013*) } & 2014**) \\
\cline { 2 - 7 } & Satuan & Februari & Agustus & Februari & Agustus & Februari \\
\hline 11) & $(2)$ & $(3)$ & $(4)$ & $(5)$ & $(6)$ & $(7)$ \\
\hline 1. Angkatan Kerja & Ribu orang & $1.577,86$ & $1.494,97$ & $1.602,53$ & $1.467,01$ & $1.570,33$ \\
\hline Bekerja & Ribu orang & $1.521,42$ & $1.447,96$ & $1.556,73$ & $1.397,25$ & $1.531,06$ \\
\hline \hline
\end{tabular}




\begin{tabular}{|l|c|c|c|c|c|c|}
\hline \multicolumn{1}{|c|}{ Penganggur } & Ribu orang & 56,43 & 47,02 & 45,80 & 69,76 & 39,27 \\
\hline 2. Tingkat Partisipas I Angkatan Kerja & $\%$ & 69,28 & 65,05 & 71,92 & 62,68 & 66,51 \\
\hline 3. Tingkat Pengangguran Terbuka & $\%$ & 3,56 & 3,5 & 2,86 & 4,76 & 2,50 \\
\hline 4. Pekerja tidak penuh & Ribu orang & 656,53 & 211,28 & 802,72 & 698,68 & 690,60 \\
\hline Setengah penganggur & Ribu orang & 254,52 & 470,62 & 187,37 & 125,35 & 164,29 \\
\hline Paruh waktu & Ribu orang & 402,01 & 681,89 & 615,35 & 573,33 & 526,30 \\
\hline
\end{tabular}

\section{Penduduk yang Bekerja Menurut Lapangan Pekerjaan Utama}

Struktur lapangan pekerjaan hingga Februari 2014 tidak mengalami perubahan, dimana Sektor Pertanian, Perdagangan, dan Jasa Kemasyarakatan secara berurutan masih menjadi penyumbang terbesar penyerapan tenaga kerja di Provinsi Jambi. Jika dibandingkan dengan keadaan Februari 2013, jumlah penduduk yang bekerja mengalami kenaikan di beberapa sektor, terutama di sektor perdagangan sebanyak 36,1 ribu orang (14,35 persen), Jasa Kemasyarakatan sebanyak 29,9 ribu orang (1,23 persen), serta Sektor Keuangan sebanyak 12,3 ribu orang (4,92 persen). Sedangkan sektor yang mengalami penurunan adalah Sektor Pertanian, Sektor Industri dan sector konstruksi.

Tabel 2. Penduduk Usia 15 Tahun Ke Atas yang Bekerja Menurut Lapangan Pekerjaan Utama, 2012-2014 (ribu orang)

\begin{tabular}{|c|c|c|c|c|c|}
\hline & \multicolumn{2}{|c|}{$2012^{*}$} & \multicolumn{2}{|c|}{ 2013*) } & \multirow{2}{*}{$\begin{array}{c}\left.2014^{* *}\right) \\
\text { Feb }\end{array}$} \\
\hline & Feb & Agus & Feb & Agus & \\
\hline (1) & (2) & (3) & (4) & (5) & (6) \\
\hline Pertanian & 858,31 & 298,76 & 846,94 & 753.82 & 753,61 \\
\hline Industri & 47,23 & 47,90 & 52,65 & 53,54 & 43,97 \\
\hline Konstruksi & 50,97 & 62,90 & 62,84 & 60,70 & 54,25 \\
\hline Perdagangan & 239,74 & 233,80 & 251,20 & 233,50 & 287,25 \\
\hline Transportasi, Pergudangan dan Komunikasi & 44,31 & 45,33 & 49,93 & 52,79 & 54,54 \\
\hline Keuangan & 27,34 & 22,64 & 25,00 & 21,93 & 37,30 \\
\hline Jasa Kemasyarakatan & 229,65 & 205,68 & 242,63 & 212,20 & 272,51 \\
\hline Lainya $* * *)$ & 23,86 & 30,94 & 25,54 & 27,6 & 25,63 \\
\hline JUMLAH & 1.521 .42 & 1.447 .96 & 1.556 .73 & 1.397 .25 & 1.531 .06 \\
\hline
\end{tabular}

*) Februari 2012-Agustus 2013 merupakan hasil backcasting dari penimbang Proyeksi Penduduk yang digunakan pada Februari 2014

**) Estimasi ketenagakerjaan Februari 2014 menggunakan penimbang hasil Proyeksi Penduduk

***) Lapangan pekerjaan utama/sektor lainnya terdiri dari: Sektor Pertambangan, Listrik, Gas, dan Air 


\section{Penduduk yang Bekerja Menurut Status Pekerjaan Utama}

Secara sederhana kegiatan formal dan informal dari penduduk yang bekerja dapat diidentifikasi berdasarkan status pekerjaan. Dari tujuh kategori status pekerjaan utama, pekerja formal mencakup kategori berusaha dengan dibantu buruh tetap dan kategori buruh/karyawan, sisanya termasuk pekerja informal. Berdasarkan identifikasi ini, maka pada Februari 2014 sebanyak 616,8 ribu orang (40,28 persen) bekerja pada kegiatan formal dan 914,3 ribu orang (59,72 persen) bekerja pada kegiatan informal.

Dalam setahun terakhir (Februari 2013-Februari 2014), penduduk bekerja dengan status berusaha dibantu buruh tetap bertambah 2,5 ribu orang dan penduduk bekerja berstatus buruh/karyawan relatif stagnan yaitu 541,7 ribu orang. Keadaan ini menyebabkan jumlah pekerja formal bertambah sekitar 2,5 ribu orang dan persentase pekerja formal naik dari 39,46 persen pada Februari 2013 menjadi 40,28 persen pada Februari 2014.

Komponen pekerja informal terdiri dari penduduk bekerja dengan status berusaha sendiri, berusaha dibantu buruh tidak tetap, pekerja bebas di pertanian, pekerja bebas di nonpertanian dan pekerja keluarga/tak dibayar. Dalam setahun terakhir (Februari 2013-Februari 2014), pekerja informal secara absolut berkurang sebanyak 28,2 ribu orang, begitu juga secara persentase pekerja informal berkurang dari 60,54 persen pada Februari 2013 menjadi 59,72 persen pada Februari 2014. Penurunan pekerja informal secara absolut ini berasal dari komponen pekerja bebas di pertanian, pekerjaan bebas di non pertanian dan pekerja keluarga/tidak di bayar.

Ada beberapa sikap pemerintah Provinsi Jambi untuk mengatasi pengangguran yaitu :

a. Sikap Pemerintah Menangani Lapangan Pekerjaan Sikap Pemerintah pada saat bertambahnya para penganggur dan juga manusia-manusia yang tidak berpendidikan yang menjadi salah satu penyebabnya.seharusnya pemerintah membuka kursus untuk ketermpilan bagi masyarakat. Salah satunya ada dengan meningkatkan peranan Balai Latihan Kerja (BLK)

b. Keterampilan yang di sediakan Seperti menjahit, bengkel, tata boga, komputer, dan keterampilan lainnya yang diperlukan oleh hotel, perusahaan motor bahkan instansi pemerintahan daerah setempat.

c. Mutu para lulusan BLK yaitu memiliki keterampilan yang tidak kalah kualitasnya 
dengan lulusan perguruan tinggi. Buktinya mantan didikan BLK sudah ada yang diminta oleh hotel-hotel ternama, perusahaan garmen, dan instansi pemerintah yang membutuhkan tenaga kerja.

\section{KESIMPULAN dan SARAN}

\section{Kesimpulan}

1. Pengangguran di Provinsi Jambi yang telah mencapai puluhan ribu orang merupakan suatu masalah yang mendesak yang harus segera dipecahkan karena dampak pengangguran itu akan sangat berbahaya bagi tatanan kehidupan sosial. Adalah fakta bahwa berbagai kejahatan sosial seperti pencurian/penodongan/perampokan, pelacuran, jula beli anak, anak jalanan dan lain-lain merupakan dampak dari pengangguran. Dilihat dari dampaknya yang luas terhadap tatanan kehidupan sosial, pengangguran telah menjadi kuman penyakit sosial yang relatif cepat menyebar, berbahaya dan beresiko tinggi menghasilkan korban sosial yang pada gilirannya menurunkan kualitas sumber daya manusia, martabat dan harga diri manusia. Karena itulah maka melalui strategi komunikasi pembangunan, kebijakan-kebijakan jangka pendek dan jangka panjang yang realistis mutlak dilakukan agar angka pengangguran dapat ditekan/dikurangi. Dengan kebijakan yang langsung menyentuh permasalahan pengangguran, maka penyebab dari berbagai patologi sosial yang dialami masyarakat saat ini dapat dikurangi. Berbagai masalah sosial perkotaan yang meresahkan masyarakat saat ini berakar dari kesulitan hidup atau kesulitan ekonomi yang disebabkan oleh ketiadaan sumberkehidupan(pekerjaan).

2. Beberapa masalah lain yang juga berpengaruh terhadap ketenagakerjaan adalah masih rendahnya arus masuk modal asing, perilaku proteksionis sejumlah negara-negara maju dalam menerima ekspor komoditi.Investasi tidak masuk ke Provinsi Jambi sehingga bias tidak adanya penyerapan tenaga kerja.

\section{Saran-saran}

1. Bagi pemerintah Provinsi Jambi, membuka sebuah lapangan pekerjaan dibidang keterampilan untuk menampung kapasitas para pencari kerja , untuk para perguruan 
tinggi dapat menciptakan keterampilan,enterprener kepada para mahasiswa sehingga setelah mereka lulus dapat membuka pekerjaan baru.

2. Kepada para peneliti yang mempuyai minat untuk mengembangkan hasil penelitian ini, kiranya perlu dilakukan kajian lebih lanjut mengenai ekonomi pembangunan terhadap pengangguran di provinsi jambi.

\section{DAFTAR PUSTAKA}

Anonim jambi dalam angka 2014, badan pusat statistic

Djoyohadikusomo, S 1990 .Perkembangan pemikiran Ekonomi (Dasar teori ekonomi pertumbuhan ekonomi dan ekonomi pembangunan) LP-3ES, Jakarta.

Ricarddson (1991) Regional growth theory. MacMillan Press Ltd London.

Soeparmoko. 1999.Ekonomi Pembangunan ,BPFE, Universitas Gajah Mada, Yogyakarta.

Sudarsono. 1989. Penetapan sasaran kesempatan kerja dan produktifitas tenaga kerja, jurnal ekonomi bisnis.

Conyer Diana, 1994. Perencanaan Sosial di Dunia Ketiga. Yogyakarta : Gajah Mada University Press.

Buku Ekonomi Pembangunan, Prayitno, Hadi . Penerbit Ghalia Indonesia 